\title{
Biodiversity of Lepidoptera in Agricultural and Horticultural Ecosystem in Pajancoa \& RI, Karaikal - U.T. of Puducherry
}

\author{
K. Thiruvengadam*, K. Sachin, J. Dharini, V. Jishnu, V. Mathivanan, \\ V. Santhiya and K. Kumar
}

Department of Agricultural Entomology, Pandit Jawaharlal Nehru College of Agriculture and Research Institute, Karaikal,( PAJANCOA \& RI) U.T. of Puducherry. India

*Corresponding author

\section{A B S T R A C T}

Keywords

Agricultural

Lepidoptera,

Horticultural

Lepidoptera,

Biodiversity and

Relative abundance

Article Info

Accepted:

18 December 2020

Available Online:

10 January 2021
Lepidopteran insects were collected at weekly intervals during kharif and rabi seasons from Agricultural and Horticultural ecosystem and identified to the extent of possible taxon's. A total of 40 fauna species of lepidopterans were recorded in agricultural and horticultural ecosystem under 40 genera, 13 families of order lepidoptera. Among the insect families, it is observed that the family Nymphalidae consists of many species followed by Lycaenidae. It was also recorded a total of 12 species under the family Nymphalidae followed by Lycaenidae (6 species). Among the collections, the number of a herbivores was maximum and comprised of 28 species when compare to tourists comprised of 12 species.

\section{Introduction}

Insects have important role in the ecosystems as herbivores, pollinators, nutrient cyclers, regulating populations of other organisms and feeding on or serving as food for other species (Losey et al., 2006). Biodiversity is a function of the number of the any taxon present or the evenness with which the taxons are distributed (species evenness or family evenness) and the interaction component of richness and evenness. Arthropods
(Lepidoptera) are the most diverse group of organism in most of the ecosystem. Butterflies are monophyletic groups but moths are paraphyletic groups within the Lepidoptera. The diversity of Lepidoptera depends on the adaptability of a species to a particular habitat as the most significant biological elements of an ecosystem are through the dimension, diversity of species and population size (Kumar, 2013). In terms of species richness, they far exceed vascular plants and vertebrates while their biomass 
within natural ecosystem exceeds that of vertebrates. The information about total Arthropod (Lepidoptera) community in AgriHorticultural ecosystems in Karaikal region, U. T Puducherry is limited. The present investigation was carried out to study the arthropod biodiversity in Agriculture and Horticulture ecosystems of Pandit Jawaharlal Nehru College of Agriculture and Research Institute (PAJANCOA and RI), Karaikal, U.T. of Puducherry, India. The farm lies between 10 52' $\mathrm{N}$ latitude and 79 52' $\mathrm{E}$ longitude with an altitude of $4 \mathrm{M}$ above Mean Sea Level. The insect collections were done in both Agricultural crops (Rice, Jute, Sesbania, Mesta, Cow pea) and Horticultural crops (Jasmine, Tuberose, Hibiscus, Bhendi, Brinjal, Citrus, Curry leaf, Mango, Nerium, Sapota).

\section{Review of literature}

Diversity indices provide important information about rarity and commonness of species in a community. The ability to quantify diversity in this way is an important tool for biologists trying to understand community structure (Beals, 1999). Varshney (1983) reported that a list of 1,150 butterfly species with their common and scientific names. He assembled all known common names of butterflies as well as shown their present valid scientific names along with family names.

Kumar (2011) worked on butterfly's abundances Bundelkhand. Nine hundred and forty eight individuals of butterflies collected from various study sites, which include 29 genera and 38 identified species belonging in six families Nymphalidae-Brush-footed Butterfly family was the most dominant with 11 species followed by Pieridae-White and yellows (10), Lycaenidae-Blues (6), Danaidae-The tigers (4), Hespiridae-Skippers (4), Papilionidae-Swallotails (3).

\section{Materials and Methods}

The insect collections were taken in both agricultural and horticultural crops like rice, cotton, sugarcane, lablab, cassava, sweet potato, pomogranate, guava, mango, sapota, moringa, curry leaf, chilli and weeds. The Arthropod fauna species were collected in the early hours of the day in the main field (8 -10 am) at weekly intervals by using different methods of collection viz., insitu and net sweeping (Hassan et al., 1995). In Net sweeping method $(32 \mathrm{~cm}$ diameter and $70 \mathrm{~cm}$ height), Above ground lepidopteran pests and predator species were trapped and monitored. Sampling done by net sweeping method in a zig zag manner at the rate of five sweepings per sampling.

The data was used to calculate the inventory of Lepidopteran fuana community. In in-situ count method, Observations on the insitu population of the natural enemies were recorded. The both methods have taken up for 10 week in Agri - Horticultural ecosystems. In Preservation, the collected insects were killed by chilling injury and wooden boxes (Uniyal and Mathur, 1998).

The method described by Tikader and Bal (1981) was followed for the preservation of the field collected soft bodied insects. In the present investigation, Relative abundance (Singh and Rai, 2000) was used to study the diversity of Lepidoptera fauna in Agricultural and Horticultural ecosystems.

Relative abundance $(\mathrm{R})=\mathrm{a} / \mathrm{N} \times 100$

Where,

$\mathrm{R}=$ Relative abundance

$\mathrm{a}=$ Total population of a particular species/taxon

$\mathrm{N}=$ Total population of all the species/taxon 
Then the total collections is divided into herbivores and tourists of Agricultural and Horticultural ecosystems. Then the data are used to find the relative abundance using equation above mentioned.

\section{Results and Discussion}

Survey was conducted from 1 st week and continued up to 10th week. The observations were recorded at weekly intervals on different crops. A total number of 33 and 24 individuals of agricultural and horticultural ecosystem were recorded and it was comprising of 12 species as tourist and 28 species as herbivores.

In agricultural ecosystem, herbivores are found dominant over tourists (both species and their relative abundance). Among the total population, the relative abundance of Danaus chrysippus, Eurema hecabe, Achraea violae, Danaus jenutia, Pelopidas mathias, Telicota ancilla, Syntarus plinius and Unidentified species were 14.49, 13.04,
$10.87,6.52,5.07,5.07,4.34$ and 5.8 percent respectively. It was observed that the lepidoptera species, Danaus chrysippus $(14.49 \%)$ which is relatively abundant followed by Eurema hecabe(13.4 $\%)$.

In horticultural ecosystem also the herbivores are found to be dominant over tourist. Among the total population, the species Danaus chrysippus, Danaus jenutia, Teliervo limniace, Achraea violae, Junonia lemonias, Junonia almona, Ergolis merione. Byblia ilithia are having 8.4, 2.52, 3.36, 10.08, 3.36, $11.76,7.56,3.36$ per cent relative abundance respectively. It was observed that the lepidoptera species, Junonia almona (11.76) were relatively abundant followed by, Achraea violae) (10.08).

A total number of 138 and 119 individuals were recorded in agricultural and horticultural ecosystem respectively which comprising of 28 species of herbivores and 12 species of tourists.

Table.1 Relative abundance of Herbivores and Tourist in Agricultural ecosystem

\begin{tabular}{|c|c|c|c|}
\hline Sl.No. & Arthropods & $\begin{array}{c}\text { Numbers / 25 } \\
\text { plants }\end{array}$ & $\begin{array}{c}\text { Relative abundance } \\
(\mathbf{\%})\end{array}$ \\
\hline $\mathbf{1}$ & Herbivores & 22 & 66.67 \\
\hline $\mathbf{2}$ & Tourist & 11 & 33.33 \\
\hline & Total & 33 & 100 \\
\hline
\end{tabular}

Table.2 Relative abundance of Herbivores and Tourist in Horticultural ecosystem

\begin{tabular}{|c|c|c|c|}
\hline SI.No. & Arthropods & $\begin{array}{c}\text { Numbers / 25 } \\
\text { plants }\end{array}$ & $\begin{array}{c}\text { Relative abundance } \\
(\mathbf{\%})\end{array}$ \\
\hline $\mathbf{1}$ & Herbivores & 15 & 62.5 \\
\hline $\mathbf{2}$ & Tourist & 9 & 37.5 \\
\hline & Total & 24 & 100 \\
\hline
\end{tabular}


Fig
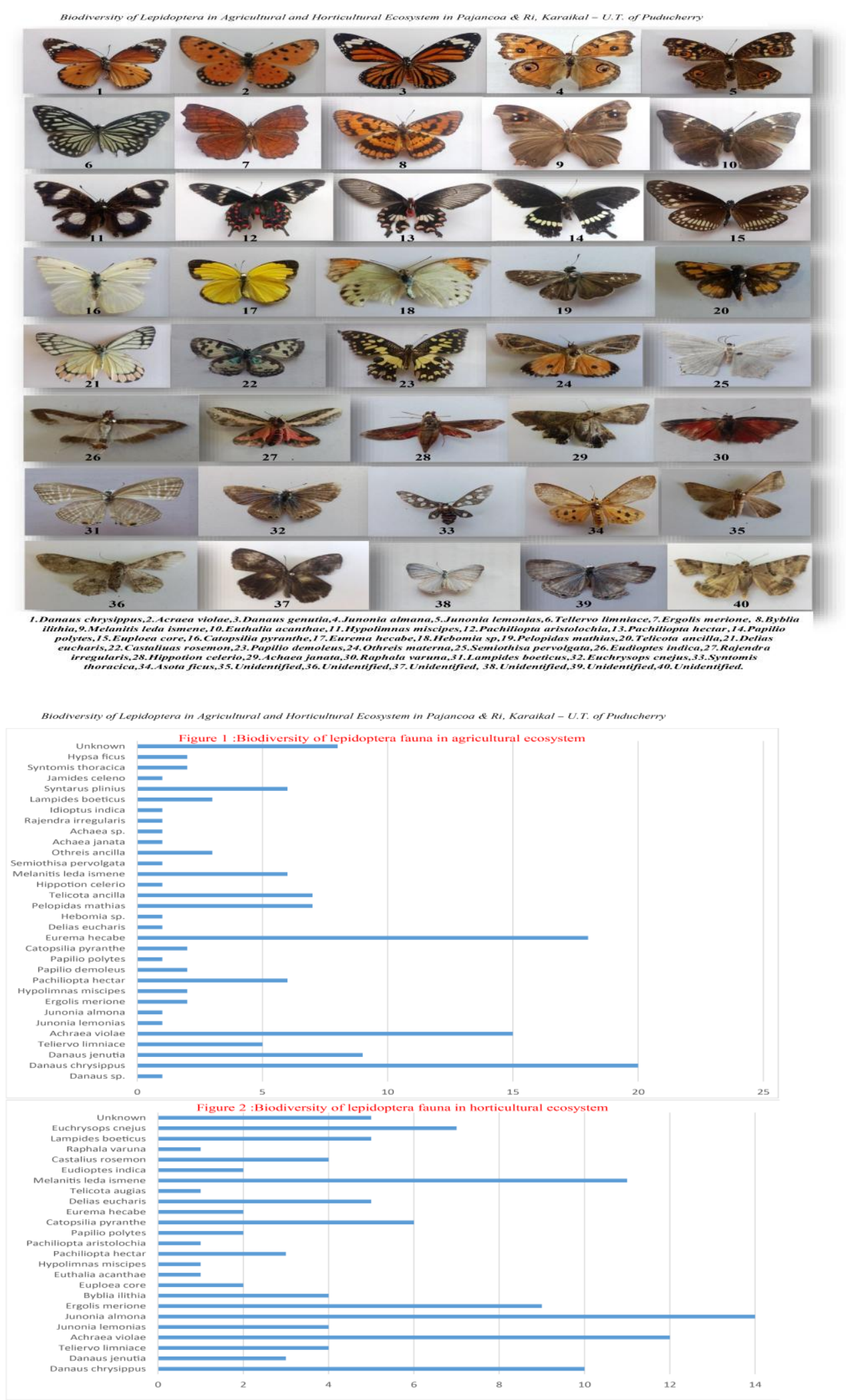
In agricultural ecosystem, the relative abundance of herbivores species namely Ergolis merione, Papilio polytes, Catopsilia pyranthe, Eurema hecabe, Delias eucharis, Hebomia sp, Pelopidas mathias, Telicota ancilla, Hippotion celerio, Melanitis leda ismene, Semiothisa pervolgata, Othreis ancilla, Achaea Janata, Achaea sp, Rajendra irregularis, Idioptus indica, Lampides boeticus, Syntarus plinius, Jamides celeno, Hypsa ficus were 1.44, 0.72, 1.44, 13.04, $0.72,0.72,5.07,5.07,0.72,4.34,0.72,2.17$, $0.72,0.72,0.72,0.72,2.17,4.34,0.72,1.44$ respectively. Among herbivores in agricultural ecosystem, Eurema hecabe found relatively abundant species followed by Pelopidas mathias and Telicota ancilla species. The relative abundance of tourists species namely Danaus sp, Danaus chrysippus, D.jenutia, Teliervo limniace, Achraea violae, Junonia lemonias, J.almona, Hypolimnas miscippus, Pachiliopta hector, Papilio demolius, Syntomis thoracica were $0.72,14.49$. 6.52, 3.62, 10.87, 0.72, 0.72, $1.44,4.34,1.44,1.44$ respectively. Among tourists in agricultural ecosystem, Danaus chrysippus found relatively abundant species followed by Achraea violae species.

In horticultural ecosystem, the relative abundance of herbivores species namely Junonia almona, Ergolis merione, Byblia ilithia, Euploea core, Euthalia aconthae, Papilio polytes, Catopsilia pyranthe, Eurema hecabe, Delias eucharis, Telicota augias, Melanitis leda ismene, Idioptus indica, Castalius rosemon, Raphala varuna, Lampides boeticus, Euchrysops cnejus were 11.76, 7.56, 3.36, 1.68, 0.84, 1.68, 5.04, 1.68, $4.2,0.84,9.24,1.68,3.36,0.84,4.2,5.88$ per cent respectively. Among herbivores in horticultural ecosystem Junonia almona found relatively abundant species followed by Melanitis leda ismene species. The relative abundance of tourists species namely Danaus chrysippus, D.jenutia, Teliervo limniace,
Achraea violae, Junonia lemonias, Hypolimnas bolina, Pachiliopta hector, Pachiliopta aristolochia were 8.4, 2.52, 3.36, $10.08, \quad 3.36,0.84,2.52,0.84$ per cent respectively. Among tourists in horticultural ecosystem Teliervo limniace found relatively abundant species followed by Danaus chrysippus species.

It can be concluded that the observed study area is positively a mini natural creators of tropical, particularly in respect to diversity of insect which needs conservation at local, regional and national levels.

\section{Acknowledgement}

The author would like to thank Dr. K. Kumar, Professor and Head (Agricultural Entomology, Pajancoa \& Ri, Karaikal, U.T. of Puducherry) for providing necessary facilities to carry out the work. We are also thankful to Dr. M. Kandibane, (Assistant Professor) for his kind support and help.

\section{References}

Beals, M.L.G., and S. Harnell. 1999. Diversity indices: Simpson's D and E. www.tiem.utk.edu/ gross/bioed/bealsmodules/simpsonDI.ht ml., pp. 3.

Hassan, S., J.M. Jensen, R.B. Graybill, W.D. Lynch and W. Sabin. 1995. Apparatus and methods for including codes in audio signals and decoding. U.S. Patent. Nielsen Audio Inc, 5, pp. 450,490 .

Kumar, A., 2013. Butterfly (Lepidoptera: insecta) diversity from different sites of Jhagadia, Ankleshwar, district-Bharuch, Gujarat. Octa Journal of Environmental Research, 1(1).

Kumar, P., A. Wanganeo, R. Wanganeo and F. Sonaullah. 2011. Seasonal variations in zooplankton diversity of railway 
pond, Sasaram, Bihar. International Journal of Environmental Sciences, 2(2), pp. 1007-1016.

Losey, J.E., and M. Vaughan. 2006. The economic value of ecological services provided by insects. Bioscience, 56(4), pp. 311-323.

Singh, N. N., and Rai Sanjeev. "Relative abundance of different coccinellids in mustard ecosystem." Indian Journal of Entomology 62, no. 4 (2000): 422-426.

Tikader and pal. 1981. The Fauna of India, butterfly: lepidoptera. Zool. Surv. India, Calcutta, II (1): pp. 533.

Uniyal, V.P. and P.K. Mathur. 1998. Diversity of butterflies in the Great Himalayan National Park, Western Himalaya. Indian Journal of Forestry, 21: pp. 150-151.

Varshney, R.K. 1985. Revised nomenclature for taxa in Wynter-Blyth's book on the butterflies on Indian region. J. Bombay nat. Hist. Sco., 82(2): pp. 309-321.

\section{How to cite this article:}

Thiruvengadam, K., K. Sachin, J. Dharini, V. Jishnu, V. Mathivanan, V.Santhiya and Kumar, K. 2021. Biodiversity of Lepidoptera in Agricultural and Horticultural Ecosystem in Pajancoa \& RI, Karaikal - U.T. of Puducherry. Int.J.Curr.Microbiol.App.Sci. 10(01): 2959-2964. doi: https://doi.org/10.20546/ijcmas.2021.1001.342 